\title{
Giant Cystic and Mediastinal Parathyroid Adenoma with Non-Uptake in Scintigraphy
}

\section{Raquel Alfonso-Ballester ${ }^{1 *}$, Ana Izquierdo Morenoํㅜ, Rosa Martí Fernández ${ }^{1}$, Nicolás Tarigo ${ }^{2}$, Norberto Cassinello Fernández ${ }^{1}$, Joaquin Ortega Serrano ${ }^{1}$}

${ }^{1}$ Department of Surgery, Clinic University Hospital of Valencia, Valencia, Spain

${ }^{2}$ General Surgery Department, Clinic Hospital, Faculty of Medicine, Republic University, Montevideo, Uruguay

Email: *raquelalfonsoballester@msn.com

How to cite this paper: Alfonso-Ballester, R., Moreno, A.I., Fernández, R.M., Tarigo, N., Fernández, N.C. and Serrano, J.O. (2018) Giant Cystic and Mediastinal Parathyroid Adenoma with Non-Uptake in Scintigraphy. Journal of Cancer Therapy, $\mathbf{9}$, 850-856.

https://doi.org/10.4236/jct.2018.911070

Received: July 24, 2018

Accepted: October 29, 2018

Published: November 1, 2018

Copyright $\odot 2018$ by authors and Scientific Research Publishing Inc. This work is licensed under the Creative Commons Attribution International License (CC BY 4.0).

http://creativecommons.org/licenses/by/4.0/

\begin{abstract}
Introduction: In $85 \%$ of patients, the cause of Primary Hyperparathyroidism (PHPT) is an adenoma. Parathyroid adenoma localization is usually simple. $96 \%$ of localizations prior to surgery are achieved with ultrasound and scintigraphy combination. Difficulties can appear. If the gland is not located in a cervical position and has no uptake in scintigraphy but there is high suspition of an adenoma causing the PHPT, some extra tests should be considered. Case Report: We present a case of giant cystic mediastinal adenoma, a quite rare condition, which was diagnosed as a thyroid colloid cyst by ultrasound, and was not localized by scintigraphy. We report the CT scan and the magnetic resonance imaging (MRI) images that show the tumour. It was surgically resected by a cervical approach. After the excision, the patient recovered normal levels of Calcium and Parathormone (PTH). Conclusion: We review literature about cystic and mediastinal adenomas and diagnostic methods when the standard ones do not give an accurate localization diagnosis.
\end{abstract}

\section{Keywords}

Primary Hyperparathyroidism, Cystic Parathyroid Adenoma, Mediastinal Parathyroid Adenoma

\section{Introduction}

The parathyroid glands can be located in an area that extends from the jaw to the pericardium, although they are mostly located in the cervical region. The superior parathyroid glands are immediately positioned in cephalic direction from the junction between the recurrent laryngeal nerve and the inferior thyroid artery, on the lateral or posterior border of the superior thyroid pedicle. They are often in contact with the thyroid capsule. The inferior parathyroid glands are 
usually located in a space limited above by the junction of the inferior thyroid artery and the recurrent laryngeal nerve, and below by the thyrothymic ligament until it enters the thorax.

In $80 \%-95 \%$ of cases, primary hyperparathyroidism (PHPT) is caused by a solitary parathyroid adenoma; less frequently it is due to pluriglandular hyperplasia $(5 \%-10 \%)$, double adenomas $(3 \%-4 \%)$ and more rarely to a parathyroid carcinoma $(1 \%-2 \%)[1]$.

The prevalence of parathyroid adenoma is $1 \%$ and it has a peak incidence in subjects between 20 and 50 year old, being more frequent among women [2] [3].

Normally, patients with PHPT are usually asymptomatic and the diagnosis of suspicion is based on a casual finding of sustained hypercalcemia. A variant in morphology is the cystic adenoma. Parathyroid cystic adenomas are traditionally classified as functioning and non-functioning and may represent up to 5\% of cystic tumors in the anterior region of the neck. Its diagnosis may be late if symptoms are not clear and the physicians do not consider this entity. Polyuria, thirst and/or nephrolithiasis may be the first manifestations of a functioning cystic adenoma.

Cervical ultrasound is the technique of choice to begin the study of an adenoma. Parathyroid scintigraphy with $99 \mathrm{mTc}$-sestamibi has sensitivities of $75 \%$ to $100 \%$ and specificities of $75 \%$ to $90 \%$. It is usually positive but we also found negative results (there is a percentage of $15 \%-20 \%$ of false negatives) in functioning cysts with high concentrations of parathyroid hormone (PTH), probably depending on the amount of coating tissue [4]. Ultrasound has a sensibility of $80 \%-90 \%$ depending on the series [5]. The ultrasound and the scintigraphy with TC $99 \mathrm{~m}$-MIBI together reach almost $100 \%$ sensitivity and a positive predictive value of $97.4 \%$. The confirmation of diagnosis will be reached through anatomopathological analysis [4] [6].

Due to the high accuracy of US and scintigraphy combination a more precise localization can be achieved and bilateral cervicotomy has been abandoned, so the major part of cases can be preoperatively localized and a minimal access surgery is nowadays the gold standard [7].

\section{Clinical Case}

We present a case of atypical localization and features and review the literature on this subject.

A 44-year-old patient with a history of allergy to penicillin, avascular necrosis in both hips followed up by rheumatologist. He has an autoimmune hypothyroidism diagnosed in 2011. He is on thyroid hormone treatment.

In September 2016 the patient consulted for osteoarticular cramps and pains, for which a laboratory review was requested. Corrected calcium was $14.2 \mathrm{gr} / \mathrm{dL}$ with PTH of $384 \mathrm{pg} / \mathrm{mL}$ Admission for endocrinal studies was decided.

During his hospital stay a cervical ultrasound (Figure 1) was performed in which a cystic formation was observed, dependent on the caudal margin of the left thyroid lobe, partially partitioned, well defined without presenting inflam- 
matory or infiltrative changes compatible with colloid cyst of thyroid origin with extrathyroidal growth. The cyst was $36 \mathrm{~mm}$ wide, but measure of the larger dimension was not assessed because it was not completely seen. Under clinical examination the lession was not palpable and no intrathoracic extension could be suspected.

In view of a primary hyperparathyroidism pending localization, a parathyroid scan with 99MTC-MIBI was requested, in which no uptake was evident. As the suspition of parathyroid adenoma causing the hyperparathyroidism was strong we ordered a computed tomography (CT scan) (Figure 2). It revealed a hypodense and well defined lession in the anterior mediastinum that contacts the most caudal portion of the thyroid lobes, without being able to correctly visualize the distal portion of the lesion as there are no thoracic cuts.

In order to assess the intrathoracic extension, and to avoid further irradiation to the patient, amagnetic resonance imaging (MRI) (Figure 3 and Figure 4) is requested in which a cystic lesion $(78 \times 37 \times 26 \mathrm{~mm})$ is observed, located in the cervicothoracic transition with anterosuperior mediastinal extension, possibly related to the thyroid without nodular enhancements. No septal contrast enhancement is seen after the administration of gadolinium to rule out cystic neoplasia.

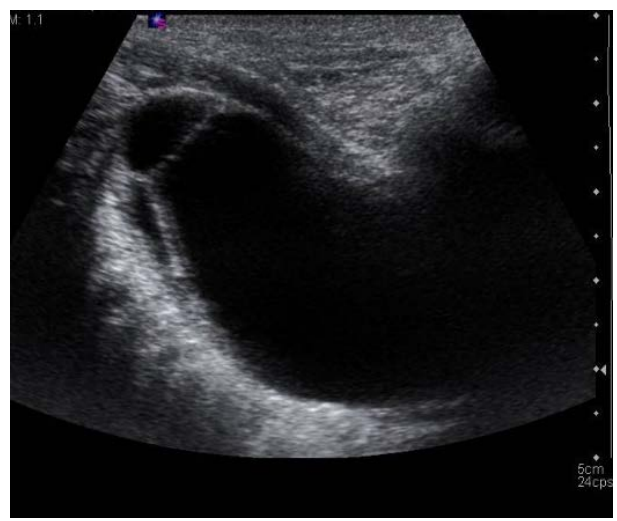

Figure 1. Cervical ultrasound showing a cystic lesion related to the thyroid gland.

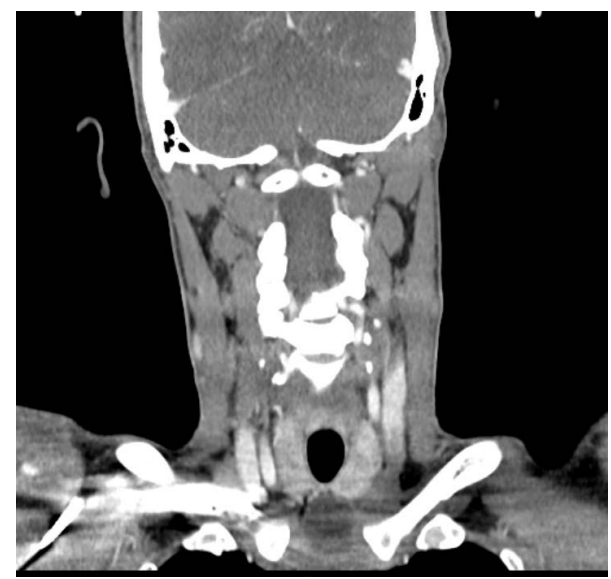

Figure 2. Cervical CT scan. A round-shaped and cystic lesion is seen depending on the inferior pole of the thyroid gland. 


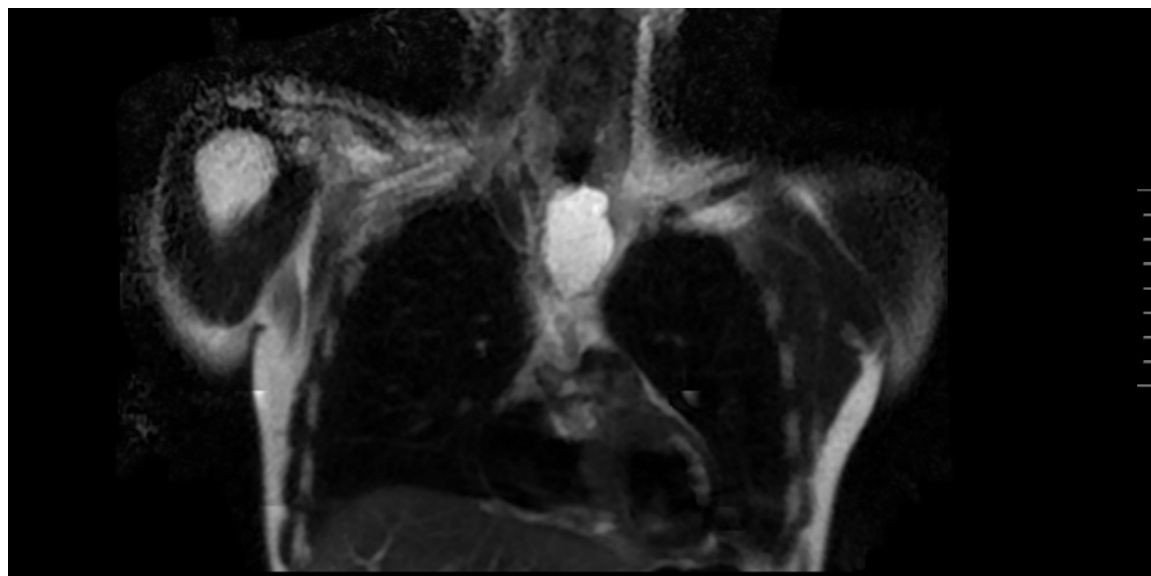

Figure 3. Thoracic MRI. The cystic mass is observed in anterior mediastinum.

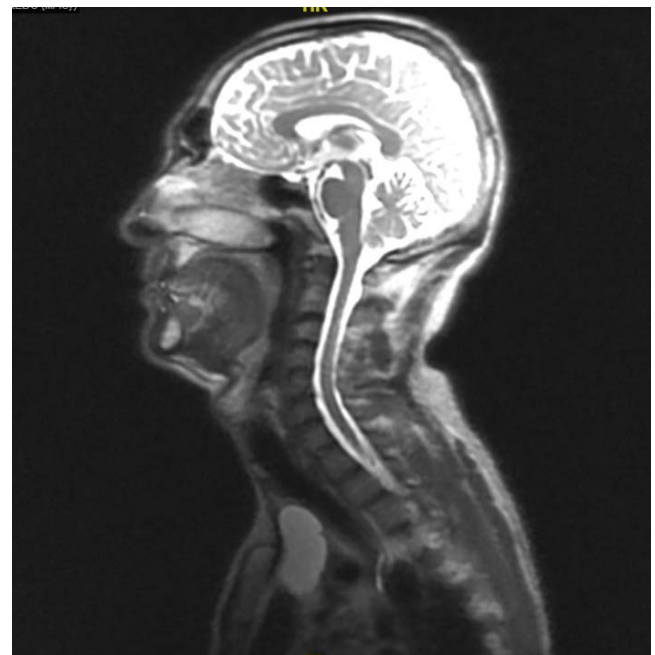

Figure 4. Thoracic MRI. Sagittal view.

According to the clinical, analytical and radiological findings, surgical intervention is decided. It is approached by anterior minicervicotomy, with intraoperative visualization of a left paratracheal cystic tumor of $80 \times 40 \mathrm{~mm}$, in intimate contact with the internal jugular vein, which is introduced up to the superior mediastinum, compatible with a cystic adenoma of the parathyroid. The upper left parathyroid gland is identified, which is of normal characteristics. The PTH figures decrease after the removal of the adenoma to 50 .

The postoperative period was uneventful, being discharged the first postoperative day with treatment with oral calcium 3 gram a day for 30 days in a descendent dose. One month after the intervention, corrected serum calcium was 9.8 $\mathrm{mg} / \mathrm{dL}$.

The pathologist study reported a parathyroid cystic adenoma without signs of malignancy.

The patient presented good clinical and analytical evolution, so he was discharged from the surgery department and referred to endocrinologist follow up. After 2 years the patient shows no recurrence. 


\section{Discussion}

Although the number and disposition of the parathyroid glands is usually standard, in the literature there are described different variants, within which the mediastinal disposition occurs in 20\% - 25\% [8]. During the embryonic period, the lower parathyroid glands descend along with the thymus, remaining at the cervical level, but there may be a descent to the mediastinum accompanying the thymus [9]. On the other hand adenoma being cystic is also extremely infrequent ( $8 \%-9 \%$ of cases) [10]. That both characteristics coincide is therefore extremely unusual. In 1996 there is a report of a cystic, mediastinal and functioning parathyroid adenoma by Gurbuz [11]. It was detected by CT scan because the Thallium-technetium subtraction scan was not diagnostic. Kammori et al. [12] report a case of cystic and mediastinal case in 2006 diagnosed by $99 \mathrm{mTc}$ sestamibi scan and CT. In 2016 Ogus reports a doble cervical and mediastinal adenoma, being the mediastinal cystic [13]. A99mTc sestamibi was diagnostic of parathyroid adenoma, and it was removed but in the postoperative period symptoms persisted. In a new $99 \mathrm{mTc}$-sestamibi scan, no abnormality was detected. Magnetic resonance demonstrated a cystic intrathoracic adenoma located anterior of the arcus aorta.

In our case, the adenoma was not identified with the usual tests (cervical ultrasound and scintigraphy), so CT and MRI were requested. The fact of being located in the mediastinum caused that it was not fully detected in the cervical ultrasound and it was misdiagnosed as a colloid cyst. Ujiki reports this as a usual mistake [14]. The CT did not provide a complete assessment because initially there was no suspicion of endothoracic situation, so the cuts were only cervical. The MRI was the test that identified the cystic mass with mediastinal prolongation.

On the other hand, scintigraphy was not diagnostic, perhaps due to the fact that the adenoma is cystic and the uptake is decreased in these cases by having little tissue in the periphery or by a more rapid elimination of the radiotracer [15]. The most accepted theory regarding the formation of functioning cystic adenomas is the degeneration, infarction or hemorrhage of the adenoma. These phenomena are more frequent in larger adenomas, as happened in our case.

All these characteristics made the diagnosis require more tests than usual. The patient was very symptomatic, and required several admissions in the emergency room until the diagnosis was made.

The presence of clinical and analytical data highly suggestive of primary hyperparathyroidism should make us exhaust the imaging tests to locate the adenoma, since it does not always appear in habitual disposition and it is convenient to have a preoperative location to avoid unnecessary cervical exploration in many cases. Cystic adenomas can be confused with thyroid cysts. In these cases, an option to be taken into account is the analysis of PTH in the FNAP of the fluid obtained from the cyst [16], although it can cause bruising and there is a risk of parathyromatosis, which is why we do not perform it. Octreoscan, 
which can detect ectopic adenomas if they express somatostatin receptors, may also be helpful [17]. The CT scan and the MRIcan also may be useful to complete the preoperative study. F-18 fluorocholine (FCH) PET/CT has been also used to detect small adenomas with success [18].

In about a $1 \%-2 \%$ of cases cervical approach is not useful and VATS should be a good option. In our case, access by minicervicotomy was satisfactory, although there are described successful video-assisted thoracoscopic accesses (VATS) in cases of totally mediastinal adenomas [19].

\section{Conclusion}

If there is a high degree of suspicion and the adenoma is not located by the routine tests (US and Scintigraphy), it is advisable to complete the preoperative localization study with other tests to avoid extensive neck exploration for such a benign condition.

\section{Conflicts of Interest}

Authors disclose any potential conflict of interest.

\section{References}

[1] Larrañaga Barrera, E. (2009) Técnica quirúrgica en la cirugía de las glándulas paratiroides. Antonio Sitges-Serra, Joan J. Sancho Insenser. Cirugía endocrina. Guías clínicas de la asociación española de cirujanos. $2^{\circ}$ edition. Madrid: Arán Ediciones, S.L., 163-175.

[2] Porras, M.L., Orozco, A.I.B. and de la Cruz Marchena Parra, M. (2009) Intraesternal Parathyroid Adenoma. Archivos de Bronconeumología, 45, 160-162. https://doi.org/10.1016/S1579-2129(09)70795-5

[3] Potts, J.T. (2005) Enfermedades de las glándulas paratiroides y otros procesos hipercalcémicos e hipocalcémicos. In: Braunwald, E., Kasper, D.L. and Harrison, F.A., Principios de medicina interna, Vol. 2. 15th Edition, McGraw-Hill, Madrid.

[4] Tardin, L., et al. (2011) Adenoma ectópico de paratiroides: Detección gammagráfica y cirugía radioguiada. Revista Española de Medicina Nuclear, 30, 19-23. https://doi.org/10.1016/j.remn.2010.09.003

[5] Murad, V., Barragán, C. and Rivera, H. (2018) Ultrasound Evaluation of the Parathyroid Glands. Revista Colombiana de Radiología, 29, 4861-4866

[6] Prats, E., Razola, P., Tardin, L., Andres, A., García, F., Abos, M.D., et al. (2007) Gammagrafía de paratiroides y cirugía radiodirigida en el hiperparatiroidismo primario. Revista Española de Medicina Nuclear, 26, 310-330. https://doi.org/10.1157/13109149

[7] Prats, E. (2009) Medicina Nuclear en el diagnóstico y tratamiento del hiperparatiroidismo primario. In: Prats, E., Razola, P., Tardin, L., Andrés, A., Santapau, A. and Banzo, J., Eds., Medicina Nuclear en la práctica clínica, Grupo Aula Médica, Madrid, 219-229.

[8] Ogawa, T., Tsuji, E., Kanauchi, H., Yamada, K., Mimura, Y. and Kaminishi, M. (2007) Excision of Postesophageal Parathyroid Adenoma in Posterior Mediastinum with Intraoperative 99mTechnetium Sestamibi Scanning. The Annals of Thoracic Surgery, 84, 1754-1756. https://doi.org/10.1016/j.athoracsur.2007.05.055 
[9] Amer, K., Khan, A.Z., Rew, D., Lagattolla, N. and Singh, N. (2015) Video Assisted Thoracoscopic Excision of Mediastinal Ectopic Parathyroid Adenomas: A UK Regional Experience. Annals of Cardiothoracic Surgery, 4, 527-534.

[10] McCoy, K.L., Yim, J.H., Zuckerbraun, B.S., Ogilvie, J.B., Peel, R.L. and Carty, S.E. (2009) Cystic Parathyroid Lesions: Functional and Nonfunctional Parathyroid Cysts. The Archives of Surgery, 144, 52-56. https://doi.org/10.1001/archsurg.2008.531

[11] Gurbuz, A.T. and Peetz, M.E. (1996) Giant Mediastinal Parathyroid Cyst: An Unusual Cause of Hypercalcemic Crisis. Case Report and Review of the Literature. Surgery, 120, 795-800. https://doi.org/10.1016/S0039-6060(96)80086-9

[12] Kammori, M., Fukami, T., Ogawa, T., Tsuji, E., Takubo, K., Nakajima, J. and Kaminishi, M. (2006) Giant Mediastinal Cystic Parathyroid Adenoma. The Journal of Clinical Endocrinology \& Metabolism, 91, 1635-1636.

https://doi.org/10.1210/jc.2006-0122

[13] Ogus, M., Mayir, B. and Dinckan, A. (2016) Mediastinal, Cystic and Functional Parathyroid Adenoma in Patients with Double Parathyroid Adenomas: A Case Report. Acta Chirurgica Belgica, 106, 736-738.

https://doi.org/10.1080/00015458.2006.11679998

[14] Ujiki, M.B., Nayar, R., Sturgeon, C. and Angelos, P. (2007) Parathyroid Cyst: Often Mistaken for a Thyroid Cyst. World Journal of Surgery, 31, 60-64. https://doi.org/10.1007/s00268-005-0748-8

[15] Oliver Guillén, J.R., de la Cueva Barrao, L., Miguelena Bobadilla, J.M., Giménez Maurel, T., Hernando Almudí, E. and Casamayor Franco, M.C. (2017) Cystic Parathyroid Adenoma: Primary Hyperparathyroidism without 99mTc-MIBI Uptake. Revista Española de Medicina Nuclear e Imagen Molecular (English Edition), 36, 254-256. https://doi.org/10.1016/j.remn.2017.01.006

[16] Guner, A., Karyagar, S., Ozkan, O., Kece, C. and Reis, E. (2011) Parathyroid Cyst: The Forgotten Diagnosis of a Neck Mass. JSCR, 8, 4.

[17] Boulahdour, H., Bertrand, A.M., Klingelschmitt, S., et al. (2002) Parathyroid Adenoma Visualization on Octreotide Scintigraphy. Clinical Nuclear Medicine, 27, 304-305. https://doi.org/10.1097/00003072-200204000-00019

[18] Michaud, L., Baloqova, S., Burgess, A., Ohnona, J., Huchet, V., Kerrou, K., et al. (2015) A Pilot Comparison of 18F-Fluorocholine PET/CT, Ultrasonography and 123I/99mTc-Sestamibi Dual Phase Dual Isotope Scintigraphy in the Preoperative Localization of Hyperfunctioning Parathyroid Glands in Primary or Secondary Hyperparathyroidism: Influence of Thyroid Anomalies. Medicine (Baltimore), 94. https://doi.org/10.1097/MD.0000000000001701

[19] Naik, D., Jebasingh, K.F., Ramprasath, G.B. and Paul, M.J. (2016) Video Assisted Thoracoscopic Surgery (VATS) for Excision of an Ectopic Anterior Mediastinal Intra-Thymic Parathyroid Adenoma. Journal of Clinical and Diagnostic Research, 10, PD22. 